\title{
Growth Performance of Three Indigenous Tree Species (Cratoxylum arborescens Vahl. Blume, Alstonia spathulata Blume, and Stemonurus scorpioides Becc.) Planted at Burned Area in Klias Peat Swamp Forest, Beaufort, Sabah, Malaysia
}

\author{
ANDY RUSSEL MOJIOL ${ }^{1}$, WAHYUDI ${ }^{2}$ AND NARBERT NASLY ${ }^{3}$, \\ ${ }^{1}$ School of International Tropical Forestry, Locked Bag 2073, Universiti Malaysia Sabah, 88999 Kota Kinabalu, Sabah; \\ Malaysia \\ 2 Department of Forestry, Faculty of Agriculture, PalangkaRayaUniversity, Palangka Raya, Indonesia \\ ${ }^{3}$ Sabah Forestry Department, Locked Bag 68, 90009 Sandakan, Sabah, Malaysia \\ Correspondence: armojiol@yahoo.com; andy@ums.edu.my
}

\begin{abstract}
The aim of the study was to evaluate the growth performance of three indigenous tree species planted under open area planting technique of burned area at Klias Peat Swamp Forest, Beaufort, Sabah. Three indigenous tree species was used in this study, namely are Cratoxylum arborescens (Vahl) Blume (Geronggang), Alstonia spathulata Blume (Pulai), and Stemonurus scorpioides Becc. (Katok). A total of 45 seedlings for each species were examined using Randomized Complete Block Design (RCBD) with spacing of $3 \mathrm{mx} 3 \mathrm{~m}$. Data collection for height, diameter, and survivality was recorded every two weeks within 10 weeks period from the seedlings was planted. Results from this study showed, the growth performance of Geronggang species was much better than the Pulai species, while all the Katok seedlings were died after week 6 in this experiment. The Geronggang species had the average mean height increment of $24.17 \mathrm{~cm}$ and average mean diameter increment of $2.76 \mathrm{~mm}$, while Pulai species had average mean height increment of $9.36 \mathrm{~cm}$ and average mean diameter increment with $1.86 \mathrm{~mm}$. For the survivality results, it showed that the Geronggang species had the highest survivality rate at $93.33 \%$ and Pulai species with $86.67 \%$. There was a significant difference in term of relative height growth rate between Geronggang and Pulai species. However, there was no significant difference in term of relative diameter growth rate at significant level of $\mathrm{P}$ $\leq 0.05$. The findings indicates that Geronggang and Pulai are suitable to be planted at burned area in Klias peat swamp forest for the purpose of reforestation using open area planting technique, while the Katok species is not suitable due to environment consideration. The better growth performance of the Geronggang and Pulai species are because they can easily adapted with the open area planting at the study site.
\end{abstract}

Keywords: peat swamp forest, burned forest area, indigenous species, growth performance, environment factor

\section{INTRODUCTION}

Based on past events in Sabah, there were over 100,000 haof peat swamp forest and almost two-thirds of it was concentrated in the Klias Peninsula, but a large amount has been ruined by repeated fires.

The closest Binsuluk Forest Reserve, in particular, has been rigorously destroyed by fire, leaving only the Klias Forest Reserve somewhat intact. Presently, it is expected that less than 40,000 haof peat swamp forest stay as an effect of habitat loss through fire and land alteration (UNDP, 2006).

Fire poses a significant threat to the conservation of peat swamp forest in Klias Forest Reserve and is expected to remain a serious threat as long as preventive measures are not taken. Forest clearing and burning for cultivation in surrounding areas during extended drought periods is likely to be the major cause of fires in Klias Forest Reserve. The fires of 1998 and 2003, which destroyed parts of the Klias IForest Reserve, bear testimony to the destructive impact of fire (Sabah Forestry Department, 2005).

For the burned area in Klias peat swamp forest, there is a need to restore to natural forest. However, it is difficult to restore to natural forest without human assistance. It is because the establishment of forest plantations especially in burned areas in peat swamp forest has many problems mainly because of the poor accessibility and low soil 
production. Thus, plantations may not be successful ventures without intensive management with high capital input (Ismail et al., 2007).

This study was carried out due to the lack of information and more research needed on planting and conserving of indigenous trees species in burned area in Klias Forest Reserve. The results obtained from this study can be used for references in rehabilitation of peat swamp forest in Klias Forest Reserve degraded area especially due to forest fire. Besides, choosing of suitable indigenous species to be planted initially in burned area to regenerated original forest is important, as maintenance cost is high if wrong species is chosen. Growth performance and survivability of these indigenous species can be used as data base for choosing the right species that can be plant initially in burned area of peat swamp forest in Klias Forest Reserve.

The main objective of this study wasto evaluate the growth performance of three indigenous tree species planted in burned area in peat swamp forest, Klias Forest Reserve. The elements that have been focused on were the growth of diameter, height and the climatic data that influenced on growth of the indigenous trees species at the site planting.

\section{MATERIAL AND METHODS}

This study was conducted in Klias Forest Reserve which is located at West Coast of Sabah, Malaysia, consists of about 3,630 ha of mixed peat swamp forest. It is situated 10 kmfrom Beaufort Town at latitude $115^{\circ} 20$ $40^{\prime}$ East and $5^{\circ} 12-15^{\prime}$ North. Most of the site comprises flat or gently undulating terrain. The annual rainfall is approximately 3690 $\mathrm{mm}$. This area is considered as one of the wet area in Sabah. Dry season is from February to March and wet season is from November to December.

Range of temperature is between $25-31^{\circ} \mathrm{C}$. The histories of this area are some of the forest reserve caught fire severely in 1998 and 2003.

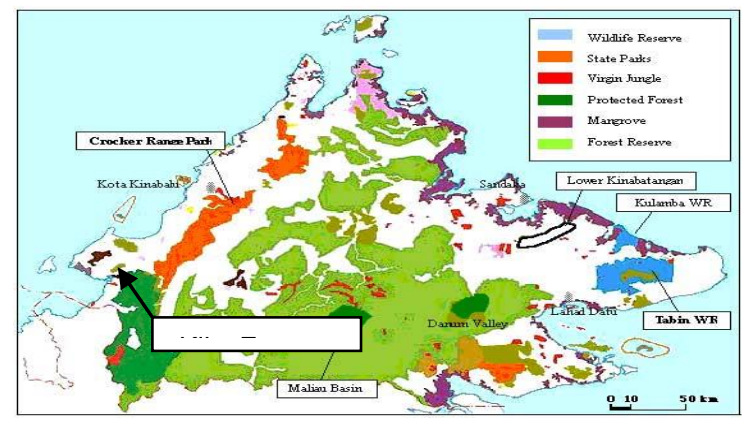

Figure 1. Location of Klias Forest Reserve in Sabah

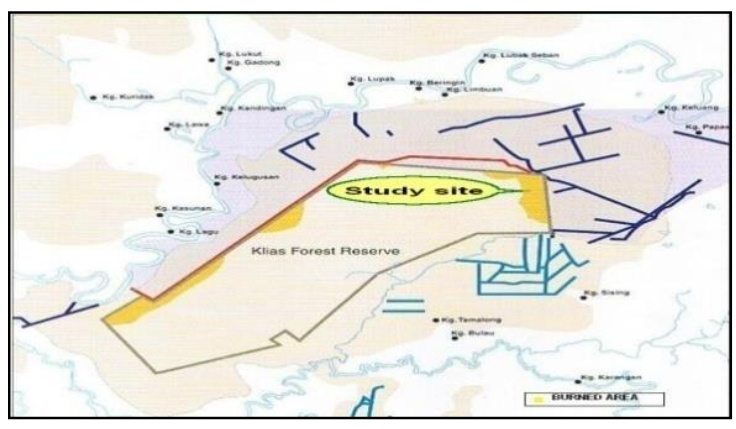

Figure 2. Location of the study site in Klias Forest Reserve, Beaufort

Experimental design. A Randomized Complete Block Design (RCBD) with Systematic Line Planting was adopted for this study with planting plot size of $15 \times 27 \mathrm{~m}$ in three replications. In each replicate, a total of 45 seedlings were planted at a spacing of $3 \mathrm{x}$ $3 \mathrm{~m}$. The total numbers of potted-seedlings planted in the burned area were 135 seedlings. The open planting method was used for this study. 
humidity for this study were based on the data provided by Sabah Meteorological Department based at Kota Kinabalu. While for the light intensity, light meter was used to measure the light intensity at the planting area. The point of the light readings was chosen randomly in the three blocks. The light meter readings were recorded twice a day, in the morning (8.00 to $9.00 \mathrm{am}$ ) and in the afternoon (1.00 to $2.00 \mathrm{pm})$ on the same day during the collecting data of diameter and height parameters. The data of soil nutrient in peat swamp area of KFR had been referred to
Sabah Agriculture Department as a secondary data in this study (Deratil et al., 2004).

Data analysis. The growth data measured for diameter and height parameters were compiled using Microsoft Excel program and subjected to the $t$-test analysis by using SPSS (Statistical Package for The Social Sciences version 12) to evaluate the significant of growth performance between the indigenous trees species. The formula as shownbelow was used to calculate the Relative Growth Rate (RGR) value in term of height and diameter for each species before subjected to the $t$-test analysis.

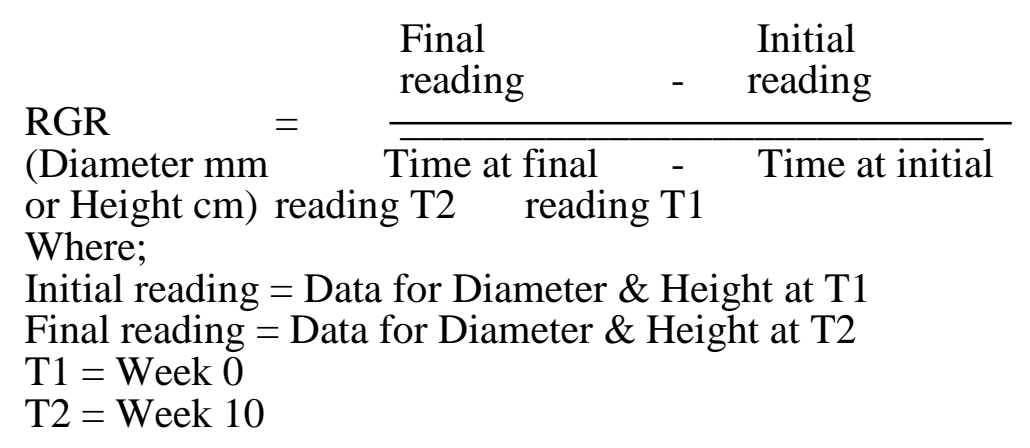

All the climatic data (light, temperature, relative humidity, and rainfalls) were compiled using Microsoft Excel program and the results have been plotted in a graph. The correlation analysis between growth of both diameter and height for each indigenous species with climatic data had been done by using SPSS (Statistical Package for The Social Sciences version 12).

\section{RESULTS}

Number of survived seedlings. The number of the seedlings survived for all indigenous trees species after 10 weeks in the 3 blocks are as shown on Table 2 . Geronggang has the highest number of seedlings survived with 42 after 10 weeks out of 45 in the initial planting, followed by Pulai with 39 out of 45 survived and none survived for Katok. All Katok seedlings died at the study site could be probably because of some environment factors that it cannot adapt.

Table 1. Number of seedlings survived after 10 weeks planted in three blocks

\begin{tabular}{|c|c|c|c|c|c|c|}
\hline \multirow{2}{*}{ Species } & \multicolumn{6}{|c|}{ Weeks } \\
\hline & $\begin{array}{c}\text { Week } \\
\text { 0 }\end{array}$ & $\begin{array}{c}\text { Week } \\
2\end{array}$ & $\begin{array}{c}\text { Week } \\
4\end{array}$ & $\begin{array}{l}\text { Week } \\
6\end{array}$ & $\begin{array}{l}\text { Week } \\
8\end{array}$ & $\begin{array}{c}\text { Week } \\
10\end{array}$ \\
\hline Geronggang & 45 & 45 & 42 & 42 & 42 & 42 \\
\hline Pulai & 45 & 43 & 40 & 40 & 40 & 39 \\
\hline Katok & 45 & 34 & 15 & 2 & 0 & 0 \\
\hline $\begin{array}{c}\text { Total of } \\
\text { seedlings survive }\end{array}$ & 135 & 122 & 97 & 84 & 82 & 81 \\
\hline
\end{tabular}


ISSN 2354-5844

Figure 4, shows the number of indigenous tree species seedlings survived during the 10 weeks. The number of seedlings that died for
Katok seedlings increased from Week 2 to Week 6. At Week 8, all the seedlings died.

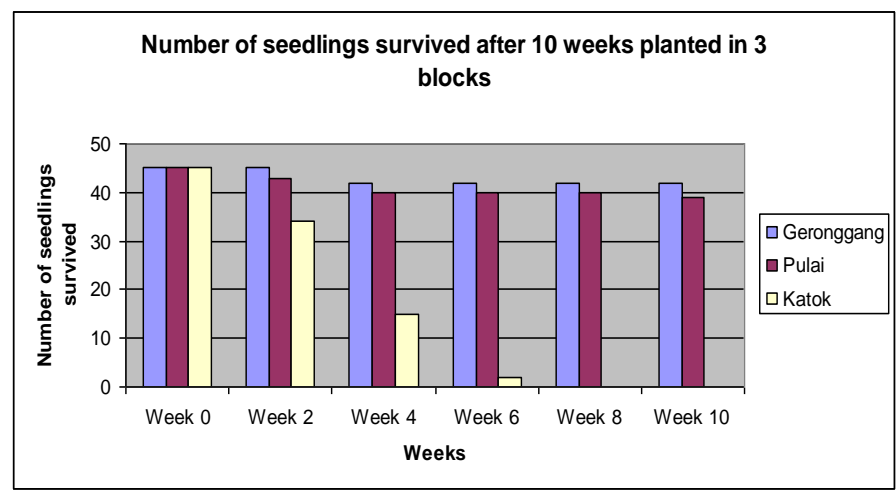

Figure 4. Number of seedlings survives in three planting blocks for 10 weeks

Survival rate $(\%)$. After 10 weeks observation, Geronggang had the highest survival rate with $93.33 \%$, followed by Pulai with $86.67 \%$ of survival rate, Katok showed a decreasing order of survival rate (Table 3 ).

Table 2. The survival rate $(\%)$ of indigenous trees speciesafter 10 weeksplanted in three planting blocks

\begin{tabular}{lcccccc}
\multirow{1}{*}{ Species } & \multicolumn{6}{c}{ Weeks } \\
\cline { 2 - 7 } & Week & Week & Week & Week & Week & Week \\
& $\mathbf{0}(\boldsymbol{\%})$ & $\mathbf{2 ( \% )}$ & $\mathbf{4 ( \% )}$ & $\mathbf{6}(\boldsymbol{\%})$ & $\mathbf{8}(\boldsymbol{\%})$ & $\mathbf{1 0}(\boldsymbol{\%})$ \\
\hline Geronggang & 100 & 100 & 93.33 & 93.33 & 93.33 & 93.33 \\
Pulai & 100 & 95.56 & 91.11 & 88.89 & 88.89 & 86.67 \\
Katok & 100 & 75.56 & 33.33 & 4.44 & 0 & 0 \\
\hline
\end{tabular}

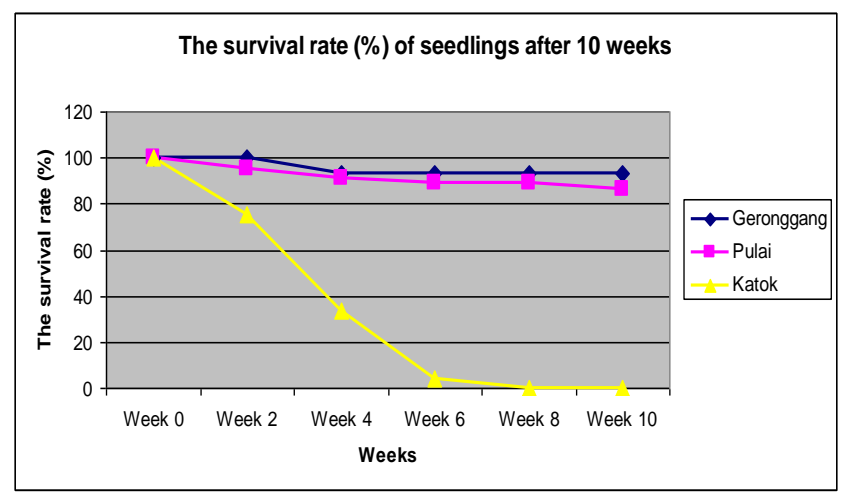

Figure 5. The survival rate $(\%)$ of indigenous trees species after 10 weeks planted in the 3 blocks

The graph on Figure 5, shows the survival rate $(\%)$ of the indigenous trees species after 10 weeks planted in three blocks.
In this study, eight of the buds seedlings of Pulai had been eaten by the wild animals but the seedlings were alive and grew. 
ISSN 2354-5844

Journal of

Wetlands Environmental Management

\section{Growth performance of indigenous trees species}

Diameter growth Table 4 shows the mean increment of diameter growth rate of the seedlings for the period of 10 weeks after planting. Geronggang and Pulai showed an

Table 3.Mean diameter increment in three blocks

\begin{tabular}{lcccccc}
\hline & \multicolumn{6}{c}{ Mean diameter $(\mathbf{m m})$} \\
& Week & Week & Week & Week & Week & Week \\
& $\mathbf{0}$ & $\mathbf{2}$ & $\mathbf{4}$ & $\mathbf{6}$ & $\mathbf{8}$ & $\mathbf{1 0}$ \\
\hline Geronggang & 0.00 & 0.41 & 0.86 & 1.39 & 2.41 & 2.76 \\
Pulai & 0.00 & 0.56 & 1.02 & 1.26 & 1.66 & 1.86 \\
\hline Katok & 0.00 & 0.30 & 0.21 & 0.02 & 0.00 & 0.00 \\
\hline
\end{tabular}

Figure 6, shows an increasing mean diameter growth rate of Geronggang and Pulai, while Katok showed decreasing in mean diameter growth rate after Week 2. The initial mean increment diameter growth rate increment in mean diameter growth rate with $2.76 \mathrm{~mm}$ and $1.86 \mathrm{~mm}$ respectively after 10 weeks. Katok showed a declining mean diameter starting from Week 2 until Week 6 when all seedlings died.

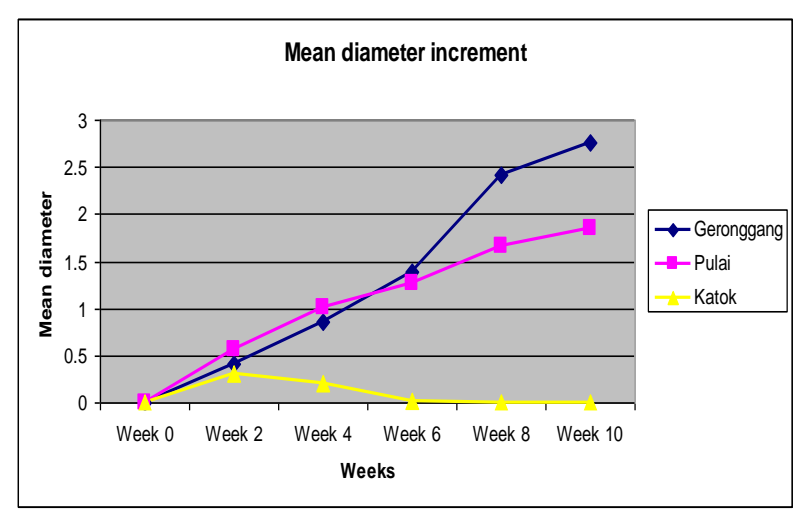

Figure 6. Mean diameter increment by species

Height growth Table 5 shows the mean increment in height growth rate of the seedlings during the 10 weeks after planting. Geronggang and Pulai showed the increment in mean height growth rate of $24.17 \mathrm{~cm}$ and $9.36 \mathrm{~cm}$, respectively after Week 10 . While Katok showed no increment in mean height after Week 8. of Pulai was faster tha Geronggang, but after Week 6 the mean increment diameter growth rate of Geronggang was more rapid than Pulai 
Table 4.Mean height increment in the 3 blocks

\begin{tabular}{lcccccc}
\hline & \multicolumn{7}{c}{ Mean height $(\mathbf{c m})$} \\
\cline { 2 - 7 } \multicolumn{1}{c}{ Species } & Week & Week & Week & Week & Week & Week \\
& 0.00 & 4.69 & 8.37 & 12.04 & 19.84 & 24.17 \\
\hline Geronggang & 0.00 & 3.60 & 5.97 & 7.60 & 9.63 & 9.36 \\
Pulai & 0.00 & 1.54 & 0.95 & 0.16 & 0.00 & 0.00 \\
Katok & & & & & $\mathbf{1 0}$ \\
\hline
\end{tabular}

Figure 7 shows the mean height growth rate of Geronggang was faster than Pulai, while Katok showed decreasing in mean height growth rate after Week 2. Table 6 shows the data for parameters MRHGR and
MRDGR for each species. For the analysis of growth performance, Katok was not subjected to this analysis because of insufficient data due to complete mortality atWeek 8 , except for Geronggang and Pulai.

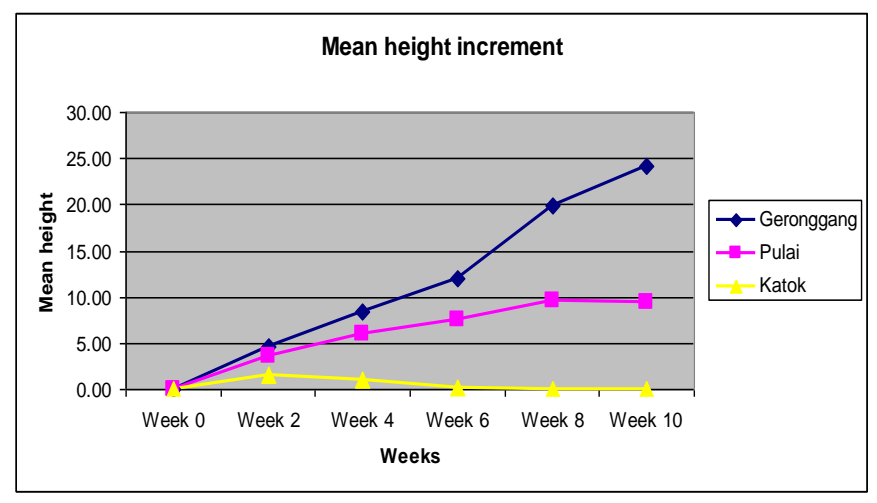

Figure 7. Mean height increment by species

Table 5. Mean Relative Height Growth Rate and mean Relative Diameter

Growth Rate for Cratoxylumarborescens species (Geronggang) and Alstonia spathulata species(Pulai) in three blocks

\begin{tabular}{clcc}
\hline Block & Species & $\begin{array}{c}\text { Mean Relative } \\
\text { Height Growth } \\
\text { Rate (MRHGR) }\end{array}$ & $\begin{array}{c}\text { Mean Relative } \\
\text { Diameter Growth } \\
\text { Rate (MRDGR) }\end{array}$ \\
\hline 1 & Geronggang & $2.49 \pm 0.68$ & $0.21 \pm 0.08$ \\
1 & Pulai & $1.30 \pm 0.57$ & $0.16 \pm 0.08$ \\
2 & Geronggang & $2.62 \pm 0.62$ & $0.31 \pm 0.11$ \\
2 & Pulai & $1.26 \pm 0.98$ & $0.21 \pm 0.10$ \\
3 & Geronggang & $2.67 \pm 0.55$ & $0.37 \pm 0.09$ \\
3 & Pulai & $1.57 \pm 0.54$ & $0.24 \pm 0.07$ \\
\hline
\end{tabular}

Data on MRDGR and MRHGR were tested for normality. From the result of the Tests of Normality (Table 7), it shows that the data on MRHGR and MRDGR for both Geronggang and Pulai were normally distributed $(P>0.05)$. 
ISSN 2354-5844

Journal of

Volume 2, Number 1, April 2014

Wetlands Environmental Management

Table 6. Tests of normality of MRHGR and MRDGR for Cratoxylumarborescensspecies

(Peronggang) and Alstonia spathulata species (Pulai) results

\begin{tabular}{llccc}
\hline Parameter & \multicolumn{1}{c}{ Species } & Statistic & $\begin{array}{c}\text { Shapiro-Wilk } \\
\text { Df }\end{array}$ & Sig. \\
\hline \multirow{2}{*}{ MRHGR } & Geronggang & 0.94 & 3 & 0.52 \\
& Pulai & 0.84 & 3 & 0.23 \\
MRDGR & Geronggang & 0.99 & 3 & 0.78 \\
& Pulai & 0.99 & 3 & 0.86 \\
\hline
\end{tabular}

$t$-test with Independent Samples Test was between species were significant. used to determine if the growth parameters

Table 7. Independent samples test results

\begin{tabular}{|c|c|c|c|c|c|c|}
\hline \multirow[b]{2}{*}{ Parameter } & & \multicolumn{2}{|c|}{$\begin{array}{l}\text { Levene's Test } \\
\text { for Equality } \\
\text { of Variances }\end{array}$} & \multicolumn{3}{|c|}{$\begin{array}{c}t \text {-test for Equality } \\
\text { of Means }\end{array}$} \\
\hline & & $\mathrm{F}$ & Sig. & $\mathrm{t}$ & $\mathrm{df}$ & $\begin{array}{l}\text { Sig. }(2- \\
\text { tailed) }\end{array}$ \\
\hline \multirow[t]{2}{*}{ MRHGR } & $\begin{array}{l}\text { Equal variances } \\
\text { assumed }\end{array}$ & 1.99 & 0.23 & 10.81 & 4 & 0 \\
\hline & $\begin{array}{l}\text { Equal variances } \\
\text { not assumed }\end{array}$ & & & 10.81 & 3.16 & 0.01 \\
\hline \multirow[t]{2}{*}{ MRDGR } & $\begin{array}{l}\text { Equal variances } \\
\text { assumed }\end{array}$ & 1.40 & 0.30 & 1.86 & 4 & 0.14 \\
\hline & $\begin{array}{l}\text { Equal variances } \\
\text { not assumed }\end{array}$ & & & 1.86 & 2.83 & 0.17 \\
\hline
\end{tabular}

Note: The significant difference level at $P \leq 0.05$.

Table 8 shows the results of t-test between Geronggang and Pulai in term of MRHGR and MRDGR. There was a significant difference of MRHGR between Geronggang and Pulai at significant difference $P \leq 0.05$ but no significant difference between both species for MRDGR $(P \geq 0.05)$. However, for diameter growth, there was no significant difference between Geronggang species and Pulai.

Correlations analysis between the growth performanc of the indigenous trees species with the climatic data. Table 13 shows correlation analyses between growth performance with climatic data. Each of the species showed no significant correlation between their growth in terms of diameter and height with the climatic data at significant correlations level $P \leq 0.05$. This mean that correlations between the growth performances of all the indigenous species with the climatic data were weak.According to Evanset al. (1992), one of the factors that influenced the growth performances of the plant planted was the environment factors that are present at the planting area, this is included the climatic data. However, in this study, the climatic data were showed nosignificant correlation with the growth of all indigenous trees species in terms of height and diameter, probably because during study, the climatic data were stable. 
Table 8. Correlations analyses results between the growth performance and the climatic data

\begin{tabular}{|c|c|c|c|c|c|}
\hline & & Temperature & $\begin{array}{c}\text { Rainfal } \\
1\end{array}$ & $\begin{array}{l}\text { Relative } \\
\text { humidity }\end{array}$ & Light \\
\hline \multirow{3}{*}{$\begin{array}{l}\text { Geronggang } \\
\text { height } \\
\text { increment }\end{array}$} & $\begin{array}{c}\text { Pearson } \\
\text { Correlation }\end{array}$ & -.644 & -.137 & .244 & .041 \\
\hline & Sig. (2-tailed) & .241 & .826 & .693 & .948 \\
\hline & $\mathrm{N}$ & 5 & 5 & 5 & 5 \\
\hline \multirow{2}{*}{$\begin{array}{l}\text { Geronggang } \\
\text { diameter } \\
\text { increment }\end{array}$} & $\begin{array}{c}\text { Pearson } \\
\text { Correlation }\end{array}$ & -.654 & -.146 & .205 & .064 \\
\hline & $\begin{array}{c}\text { Sig. (2-tailed) } \\
N\end{array}$ & $\begin{array}{c}.231 \\
5\end{array}$ & $\begin{array}{c}.815 \\
5\end{array}$ & $\begin{array}{c}.741 \\
5\end{array}$ & $\begin{array}{c}.919 \\
5\end{array}$ \\
\hline \multirow{2}{*}{$\begin{array}{c}\text { Pulai } \\
\text { height } \\
\text { increment }\end{array}$} & $\begin{array}{c}\text { Pearson } \\
\text { Correlation }\end{array}$ & -.482 & -.093 & -.093 & .242 \\
\hline & $\begin{array}{c}\text { Sig. (2-tailed) } \\
\mathrm{N}\end{array}$ & $\begin{array}{c}.411 \\
5\end{array}$ & $\begin{array}{c}.881 \\
5\end{array}$ & $\begin{array}{c}.882 \\
5\end{array}$ & $\begin{array}{c}.695 \\
5\end{array}$ \\
\hline \multirow{2}{*}{$\begin{array}{c}\text { Pulai } \\
\text { diameter } \\
\text { increment }\end{array}$} & $\begin{array}{l}\text { Pearson } \\
\text { Correlation }\end{array}$ & -.508 & -.093 & .052 & .166 \\
\hline & $\begin{array}{c}\text { Sig. (2-tailed) } \\
\mathrm{N}\end{array}$ & $\begin{array}{c}.382 \\
5\end{array}$ & $\begin{array}{c}.881 \\
5\end{array}$ & $\begin{array}{c}.933 \\
5\end{array}$ & $\begin{array}{c}.790 \\
5\end{array}$ \\
\hline \multirow{2}{*}{$\begin{array}{c}\text { Katok } \\
\text { height } \\
\text { increment }\end{array}$} & $\begin{array}{l}\text { Pearson } \\
\text { Correlation }\end{array}$ & .398 & -.122 & .206 & -.142 \\
\hline & $\begin{array}{c}\text { Sig. (2-tailed) } \\
\text { N }\end{array}$ & $\begin{array}{c}.507 \\
5\end{array}$ & $\begin{array}{c}.845 \\
5\end{array}$ & $\begin{array}{c}.740 \\
5\end{array}$ & $\begin{array}{c}.820 \\
5\end{array}$ \\
\hline \multirow{2}{*}{$\begin{array}{c}\text { Katok } \\
\text { Diameter } \\
\text { increment }\end{array}$} & $\begin{array}{c}\text { Pearson } \\
\text { Correlation }\end{array}$ & .432 & -.174 & .186 & -.067 \\
\hline & $\begin{array}{l}\text { Sig. (2-tailed) } \\
\mathrm{N}\end{array}$ & $\begin{array}{c}.467 \\
5\end{array}$ & $\begin{array}{c}.780 \\
5\end{array}$ & $\begin{array}{c}.764 \\
5\end{array}$ & $\begin{array}{c}.915 \\
5\end{array}$ \\
\hline
\end{tabular}

Note: Correlation is significant at the P $\leq 0.05$ level (2-tailed

\section{DISCUSSIONS}

\section{Growth performance of indigenous trees} species from the results this study, Geronggang had performed better growth performance in terms of survival rate $(\%)$ and the growth of both diameter and height compared to Pulai. Pulai had also showed a better result of growth performance in term of survival percentage and both diameter and height growth.However, the bud of Pulai seedlings were more susceptible to be eaten by the wild animals. For Katok, all the seedlings were died due to the condition of the some environment factors they cannot adapt at their early growth. The environment factors were light, temperature, relative humidity (\%), rainfall distribution, and nutrient peat soil.
Geronggang and Pulai showed better growth because they could tolerate the environment factors that influence the growth performance. The growth performances of the indigenous trees species were influenced by this environmental factors (Evans et al., 1992). These environment factors included light intensity, temperature, relative humidity (\%), rainfall distribution, and nutrition in the peat soil as discussed in the following the next topic.

\section{Environment factors that affecting the growth performance}

Light intensity. Janick et al. (1981) stated that light provides the energy for the synthesis of the Ccompounds in plants. It also has great effect on physiological processes. Germination, flowering, dormancy, and plant movement processes also directly affected by light. Light affects the segregation of many 
plant tissues and organs. It is also a source of heat received by plant from irradiation of long wavelengths outside of the visible range. Plant growth depends on the amount of Cfixed during photosynthesis. Neither photosynthesis nor chloroplast development can take place without light. Even though the process of photosynthesis depends on the availability of light, the more sunlight a plant receives, the better capacity it has to produce plant food through photosynthesis. However, for each plant species, there is a maximum level of light intensity above which photosynthesis does not increase.

On the study site, all the seedlings received sufficient light intensity without interference from any vegetation except the cloud. It means, all the seedlings received light to do their photosynthesis process to growth. For Geronggangand Pulai seedlings, the light intensity that they received had assisted them to produce plant food through photosynthesis. This could have influenced the better results in growth performance for these species. For Katok, this is a shade tolerant species which cannot stand direct sun light at their early growth (Sumarto, 2007: personal communication). A high light intensity could lead to death of the plants. So, to get a better growth, this species needs a good shade at the early growth. In this study, Katok was used in the open planting technique due to lack of information whether this species can survive under this technique or not.

Rainfall. Young (1982) reported that when the internal moisture content of a tree decreases, many physiological processes are affected adversely, resulting in growth loss. Among the processes influenced by water shortage are absorption of water stomata aperture, transpiration, photosynthesis, respiration, and mineral uptake.

Based on the rainfall data recorded at the Klias Station, the Klias area received a mean daily rainfall of $10.35 \mathrm{~mm}$ from September to November 2007. The rainwater received at the study site diffused directly into the ground and was absorbed by the roots of the seedlings planted. This means that all the seedlings received water as their primary component to do many physiological processes. As Geronggangand Pulai grew well at the study site indicating that the amount of water they need were adequate. On the other hand, Katok, the amount of water received was probably inadequate for their many physiological processes resulting in growth loss.

Temperature. According to Ismail and Yaakob (1994), plants need suitable temperature to be able to grow. This can be seen in the growth of the plant itself. At an optimum temperature, plant growth occurs at an optimum rate. This situation is called plant cardinal temperature. Plant cardinal temperature differs according to different types of plant. If the temperature for certain species drops below its minimum cardinal temperature in certain areas, the metabolic activity of the species will be slower than its normal rate, whereas if the temperature is higher than the cardinal temperature of the species, this situation might damage the growth cells of the plant.

The mean temperature reading recorded in September was $27.2^{\circ} \mathrm{C}$, October, $27.4{ }^{\circ} \mathrm{C}$ and in November, $26.6{ }^{\circ} \mathrm{C}$. This showed that the mean temperature reading was between the range where most plants live and grow which is within the temperature range of $0^{\circ} \mathrm{C}$ to $50^{\circ} \mathrm{C}$ (McMahon et al., 2002).

For Geronggang and Pulai, better growth performance shown by this two species indicated that the mean temperatures that were recorded from September to November were in the range of their cardinal temperature. This means, the highest mean temperature of $27.4{ }^{\circ} \mathrm{C}$ was tolerable for the growth of Geronggang and Pulai. Meanwhile, for Katok, the mean temperatures from September to November were probably not in the range of their cardinal temperature. This could be higher than its cardinal temperature, hence damaged the growth cells and influenced the death of all Katok seedlings. 
Relative humidity (\%). According to Ismail and Yaakob (1994), air humidity surrounding the plants is a major factor that influences the loss of water from plants through the process of transpiration. Transpiration rate increases if the air humidity in the surrounding plants is at low level. This happens because low level of humidity means the air surrounding the plants is dry and contains less water vapour. The low level of humidity will expedite water transpiration process within plants. The transpiration process takes place through the leaf stoma or the cuticle layer of the epidermis cell. If plants lacks moisture, it will in turn affect all the activities that occur within it. This is because water is an important element in the photosynthesis process and also acts as a solvent agent to other chemical substances needed by plants. Therefore, a lack of water content in plants will directly affect the plant growth performance.

Based on data recorded at the Kota Kinabalu Station, the relative humidity in September was $83.1 \%$, October was 81.7 $\%$, and November was $83 \%$. This reading indicates that the surrounding area at the planting site were high in relative humidity. This was an advantage for all the seedlings in the study site for water retention, especially for Geronggang and Pulai seedlings. However, this situation was not the cause of the death of all Katok seedlings at the study site.

Nutrients in Klias peat swamp forest. Based on the findings from a previous study carried out by the Sabah Agricultural Department (Deratil et al., 2004), the properties of peat soils of surrounding Klias areas pose severe restriction to agricultural development. One of the reasons wasdeficiency in soil nutrients, thus, peat soils were not the best for agricultural practices. These findings were very important as it influenced the growth performance of the indigenous trees seedlings that have been planted.
According to Young (1982), mineral nutrients have many functions in trees, such as constituent of plant tissues, catalyst in various reactions, osmotic regulators, constituents of buffer systems, and regulators of membrane permeability. If plants are subject to mineral deficiency, the most important general effect to plants is reduced growth, but the earliest and most conspicuous response is leaf yellowing, a condition called chlorosis, caused by reduced synthesis of chlorophyll. The rate of photosynthesis is greatly reduced in chlorotic trees. Other common symptoms of mineral deficiency include leaf spots, marginal scorching, dieback or shoots, rossetting, fusion of needles, and injury to reproductive structures.

Based on the growth performance of Geronggangand Pulai, several of the seedlings showed the symptoms of mineral nutrient deficiency like leaf spots, but the seedlings still grew well after 10 weeks. For Katok, the death for all of these seedlings was probably not because of the mineral nutrient deficiency on the study site.

Limitation of the study. From the study that has been carried out, several limitations have been identified;

i. Klias Peat Swamp Forest quite far from KotaKinabaluTownwhereas nearly $130 \mathrm{~km}$. Therefore,it is very difficult to access easily to this study site especially in collecting data such as rainfall distribution, relative humidity (\%), temperature and light intensity.

ii. During the study, eight buds Pulai seedlings at the study site had been eaten by the wild animals in the jungle. This might be interrupt the data collection results.

\section{CONCLUSIONS}

From the study that has been carried out, it was found that Geronggang has the highest survival rate at93.33 \%, followed by Pulai with $86.67 \%$. However, none of Katok seedlings survived at the study site. For growth performance, Geronggang performed 
better than Pulai. There was a significant difference of height growth rate between Geronggang and Pulai at significant level $P \leq 0.05$, but there was no significant difference in terms of diameter growth rate $(P \geq 0.05)$.

The conclusions from this study were;

i. Geronggang and Pulai are suitable for planting under open planting method at the degraded area in Klias Forest Reserved due to forest fire because this species can adapt with the environment factors present at the study area.

ii. Katokwerenot survive at this area for their early growth probably because of high temperature, inadequate of water from rainfall, and the large amount of light intensity on the study site.

iii. The growth performance of the indigenous trees seedlings were influenced by environment factors present at the study site. These factors are light intensity, temperature, air relative humidity, rainfall distribution, and nutrient in the peat soils.

\section{ACKNOWLEDGEMENT}

Special thanks to the Director of Sabah Forestry Department, Datuk Sam Mannan, for giving his permission to conduct this research at Klias Forest Reserved, Beaufort. In addition, we would also like to express our gratitude to the staffs of Sabah Forestry Department especially to Mr. Christhoper Matunjau, Mr. Alexander Gervasius, Mr. Somarto Selamat, Dr. Ruben Nilus and Mr. Jupiri Titin, Mr. Peter Jack and Mr. Jarry Lajanga for their assistance and contribution of ideas in doing this research. Our acknowledgement also goes to the Sabah Metereological Department for allowing us to use the climatic data.

\section{REFERENCES}

Ahmad Zuhaidi Y. and Weiland, G., 2002. MalayanForest Records No. 45. A Manual for Forest Plantation Establishment in Malaysia. Forest
Plantations: Establishment Techniques, pp. 89-92. Forest Research Institute Malaysia: Perpustakaan Negara Malaysia. Appanah, S., 1997. Peat Swamp Forests Of Peninsular Malaysia: The Endangered Ecosystem. Proceedings of The Workshop on Sustainable Management of PeatSwampForest. $29^{\text {th }}$ September to $1^{\text {st }}$ October 1997. Kuala Lumpur.

Burgess, P. F., 1966. Timbers of Sabah. (SabahForest Records No. 6). SandakanMalaysia: Sabah Forestry Department.

Deratil Boaklan, Jenny N.L. Lee and Elizabeth Malangkig, 2004. Conservation And Management Of PeatSwampForests And Other Wetlands In Sabah: Issues And Challenges. Capacity Evaluation of The Peatland in Kuala Penyu and Beaufort for Sustainable Agricultural Development: Proceedings of The NinthSabahInterAgency Tropical Ecosystem (SITE) Research Seminar. Kota Kinabalu. 66-78.

Evan, J., Wood, P. J. and Montanda, A., 1992. The use of Tropical Plantations in Sustainable Forest Management. In Peter. J. Wood, Jerome K. Vanclay and Wan Razali Wan Mohd. (Eds). In Proceedings of the tropical silviculture workshop at the IUFRO centennial conference in Berlin, pp 148. Forest Research Institute Malaysia: Kuala Lumpur.

Ismail Ahmad and Yaakob Mohd. Jani, 1994. Tumbuh-tumbuhan dan persekitaran, satu perspektif geografi. Kuala Lumpur: Dewan Bahasa dan Pustaka.

Ismail , P., Shamsudin, I., Abdul Rahman, K., Hashim W. S. and Ismail, H., 2007. Planting of Gonystylus bancananus In Non-Peat Swamp Area. Journal Of TropicalForest Science 19(1):50-56.

Ismail, P., Shamsudin, I., Nik Muhamamad, N. M. and Faridah Hanum, 2003. Rehabilitation Of Degraded Peat Swamp Forests in Raja Musa Forest Reserve, Selangor, Peninsular Malaysia: Paper presented at the XII World Forestry Congress, September, Quebec City, Canada.

Janick J., Schery, R. W. and Ruttan V. W., 1981. Plant science, an introduction to world crops ( $3^{\text {rd }}$ Ed.). San Francisco: W. H. Freeman and Company.

Kramer, P. J., 1983. Water Relations of Plants. London: Academic Press. Inc. 
McMahon, M. J., Kofranek, A. M. and Rubatzky, V.E., 2002. Hartmann's Plant Science. ( $3^{\text {rd }}$ Ed.) New Jersey, United States of America: Prentice Hall.

Rieley, J. O., Ahmad Shah, A. A. and Brady, M. A. 1., 1995. Tropical Peat Swamp Forests of Southeast Asia: Ecology and Environmental Importance. Malaysia Journal of Tropical Geography. 26(2): 131-141.

Sabah Forestry Department, 1999. Forests Of The Bukau-Api-ApiRiver Area, KliasPeninsula. A Botanical Assessment \&Conservation Perspective. Sandakan: Sabah Forestry Department.

Sabah Forestry Department, 2005. KliasPeatSwampForest, Sabah, Malaysia. Hydrological Processes and Strategies for Water Management. Sandakan:Sabah Forestry Department.

Soepadmo, E. and Wong, K. M., 1995. Tree Flora of Sabah and Sarawak. Vol. One. Malaysia: Sabah Forestry Department, Forest Research Institute Malaysia \& Sarawak Forestry Department.

Soepadmo, E. and Wong, K. M., 2004. Tree Flora of Sabah and Sarawak. Vol. Five.
Malaysia. Sabah Forestry Department, Forest Research Institute Malaysia\&Sarawak Forestry Department. Malaysia.

Sumarto Selamat, 2007. Assistance Research at Klias Station. Personal communication. $18^{\text {th }}$ November 2007.

United Nations Development Program (UNDP), 2006. Malaysia's Peat Swamp Forest Conservation and Sustainable Use. Kuala Lumpur: UNDP.

Whitmore, T. C., 1984. Tropical Rainforest of The Far East. (2 ${ }^{\text {nd }}$ edn). Oxford: Clarendon Press.

Young, R. A., 1982. Introduction to Forest Science. New York: John Wiley \& Sons. 